\title{
Study of prevalence and intensity of ectoparasites in cultivated green mussel (Perna viridis L.) in Alue Naga Waters, Banda Aceh
}

\author{
Ichsan Rusydi ${ }^{1,4^{*}}$, Nadiatul Salsabila ${ }^{2}$, Cut Nanda Defira $^{3}$, Sayyid Afdhal ElRahimi ${ }^{2,4}$, Kavinta Melanie ${ }^{2,4}$, Dedi \\ Fazriansyah Putra ${ }^{2,4}$, Afriliana Afriliana ${ }^{5}$, and Fahmi Fahmi $^{6}$ \\ ${ }^{1}$ Department of Marine Science, Faculty of Marine and Fisheries, Syiah Kuala University, Indonesia \\ ${ }^{2}$ Department of Aquaculture, Faculty of Marine and Fisheries, Syiah Kuala University, Indonesia \\ ${ }^{3}$ Biology Department, Faculty of Mathematics and Natural Sciences Universitas Syiah Kuala Banda Aceh 23111, Indonesia \\ ${ }^{4}$ Research Center for Marine Sciences and Fisheries, Universitas Syiah Kuala, Banda Aceh 23111, Indonesia \\ ${ }^{5}$ Fishery instructor, Ministry Of Marine Affairs And Fisheries Republic Of Indonesia \\ ${ }^{6}$ School of Forestry Science Tgk. Chik Pante Kulu
}

\begin{abstract}
Parasites are a major problem on biota survival or green mussels because parasites are organisms that live in other organisms. Parasites can harm the host they live in because these organisms will absorb nutrients from the host they live on, damage tissues, and cause infection. This study aims to examine the types of ectoparasites and to determine the prevalence and intensity values of cultivated green mussels (Perna Viridis L.) in the Alue Naga reservoir, Banda Aceh. The study was conducted in July 2020, identification of parasites was carried out at the Fish Quarantine Station, Quality Control and Safety of Class 1 Fishery Products in Aceh. The research method was a survey method with a sampling technique using random sampling. Observations were made visually and using a microscope on the target organs in the shell, gills, and mantle. Furthermore, the parasites found in green mussels were identified using the Kabata book (1984). Based on the research results found 4 types of ectoparasites, namely cysts perkinsus sp. (Protozoa) on the coat, Balanus sp. (Crustacea) on the shell, Monogenea (Platyhelminthes) on the gills, Copepoda (Crustacea) on the gills, and it is known that the highest intensity value is 1.16 and the highest prevalence value is $74 \%$. parasite barnacles (Balanus sp.), while the lowest intensity value is 1 and the prevalence value is $1 \%$ cysts perkinsus sp. The water quality values were $\mathrm{pH} 8.7$, temperature $29 \mathrm{C}$, dissolved oxygen 4.8 Ppm, salinity $31 \mathrm{Ppt}$, depth $1.53 \mathrm{~m}$, brightness $70 \mathrm{~cm}$, and current $17 \mathrm{~m} / \mathrm{s}$. The value of water quality parameters in Alue Naga waters is still in the optimum range for the growth of green mussels.
\end{abstract}

\section{Introduction}

The presence of green mussels (Perna Viridis L.) (Bilvavia Phylum Mollusca Class) is widespread in Indonesian waters and it is abundantly found in coastal waters, reservoirs, mangroves, and river estuaries. Therefore, many coastal communities grow green mussels as a side income in their free time [1]. This statement is also supported by [2], that green mussels have potential value to be cultivated, considering the availability of green mussels in nature will having a decrease due to the increased capture.

Aceh waters are one of the waters that have high diversity. One of the organisms that have high diversity is in the bilvavia phylum mollusks class. The organisms categorized to the bivalve's class are green mussels (Perna viridis $\mathrm{L}$.). Alue Naga waters, Banda Aceh is one of the waters in Aceh that green mussels are available. Green mussel (Perna viridis L.) is a type of aquatic organism that lives on the bottom substrate of the waters and attaches to a hard substrate. Green mussels (Perna viridis $\mathrm{L}$.) are shellfish that have high economic value and it is favorite food by the public because of their high nutrients content.
Parasites are a major problem in the biota survival or green mussels because parasites are organisms that live on the bodies of other organisms. Parasites can harm the host they live in because these organisms will absorb nutrients from the host they are attaching to, damage tissues, and cause infection. Parasites can be protozoa, worms, bacteria, viruses, and fungi [3].

The environment of shellfish resources is a place for shellfish to live includes biota and natural factors surrounding it. One of the often diseases attack green mussels (Perna viridis L.) is a parasitic disease. The parasites are divided into two groups, there are groups of ectoparasites and endoparasites group. Ectoparasites are parasites that live attaching to the outside of the host's body, endoparasites are parasites that live inside of the host's body. The types of ectoparasites attacking green mussels are Balanus sp., Perkinsus sp. and Nematodes [4].

The cultivated green mussels in Alue Naga need to be examined for parasites to determine the type of parasite that infects green mussels. Because the appearance of disease attacks is caused by many things, one of them is the inappropriate result of the interactions to the environmental conditions that cause disease. In 
the appropriate interactions, it is strongly influenced by the survival of shellfish. Because the mechanisms of defense of the shell's body do not work optimally so that the infectious disease is easy attacking the body shells.

Management of shrimp ponds that are not environmentally friendly can cause poor quality of marine waters, this can be seen from the existence of ponds that do not have water treatment ponds, where the waste products are directly discharged into the sea. In research [5], in terms of sea water quality, the coastal waters of Probolinggo Regency are categorized as moderate pollution. The results of the study of COD in the sea obtained an average of $17.9 \mathrm{mg} / \mathrm{l}$ presented in table 1. This COD value is still in the range of environmental quality standards, namely $<20 \mathrm{mg} / 1$ [6].

High levels of COD reflect high concentrations of organic compounds in the waters or a decrease in the health of aquatic ecosystems. The COD (KMnO4) concentration should be below $3 \mathrm{mg} / \mathrm{l}$ on the coast and for aquaculture. The COD level in this study, found to be almost the same as that conducted by [7] (14.7-58.9 $\mathrm{mg} / \mathrm{l})$ in different areas, because the field of research results is strongly influenced by shrimp pond waste as well as urban pollution and household waste disposal.

Therefore, it is important that this study was conducted with the aim of assessing the types of ectoparasites and to determine the prevalence and intensity values of green mussels (Perna viridis L.) from aquaculture in the Alue Naga reservoir, Banda Aceh.

\section{Research Method}

\subsection{Time and Place}

This research is conducted in Alue Naga Reservoir, Banda Aceh, Aceh Province. The research Time performed in July 2020 and the identification will be conducted at stations Quarantine Fish, Control of Quality and Safety Results Fishing Class 1 Aceh. The Research map at Alue Naga Reservoir, Banda Aceh can be seen in Figure 3.1 as follows:

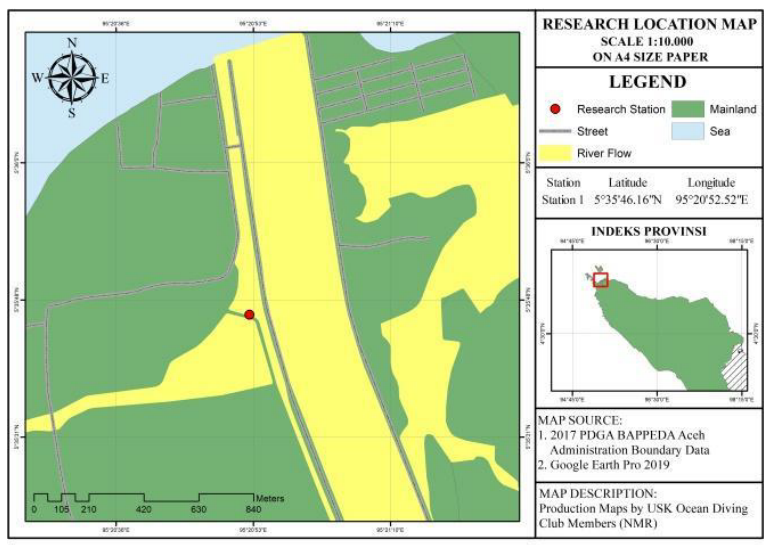

Fig 1. Research location Map

\subsection{Experimental Design}

\subsubsection{Determination Observation Station}

The method in the research used the survey method and samples were taken by random sampling technique, the sampling techniques are random, which each population has a similar chance to be selected as the sample. The sampling was conducted on cultivated green mussel containers and the samples used about 100 mussels, with an average long $4-7 \mathrm{~cm}$ and an average weight of 5-6 g. The mussels taken are filled into a plastic containing a bit of water and oxygen on it and then it is brought to a laboratory for ectoparasite examination and microscopically examined

\subsubsection{Capturing and Sample Treatment}

Green mussels sampling was catching by hand then recording the, observing clinical symptoms (the presence of organisms attached to the shell and pale gill color), measuring the length and weight of green mussels, and making range preparations by cutting the target organs, such as the shell and gills. The results of targets organ pieces are placed on the top of slide glass, then the observation would be performed using a microscope. Furthermore, the parasites found in green mussels were identified using the kabata book (1984). The data collected in this study include the value of the prevalence and intensity values, besides, it also retrieved data from the measurement quality of water such as, oxygen dissolved (DO), $\mathrm{pH}$, and temperature of the water.

In this study, efforts to engineer containers and green mussel cultivation technology in the waters of the Alue Naga reservoir were carried out, this is reinforced in References [8], by taking into account the construction of the container properly and correctly, a fish culture container that has a long service life will be obtained. The technical requirements that must be considered in choosing the location of a fish farming business in floating net cages include: Currents, tides, water fertility levels, free from pollution. After obtaining a location that meets technical and socio-economic requirements, planning must be carried out.

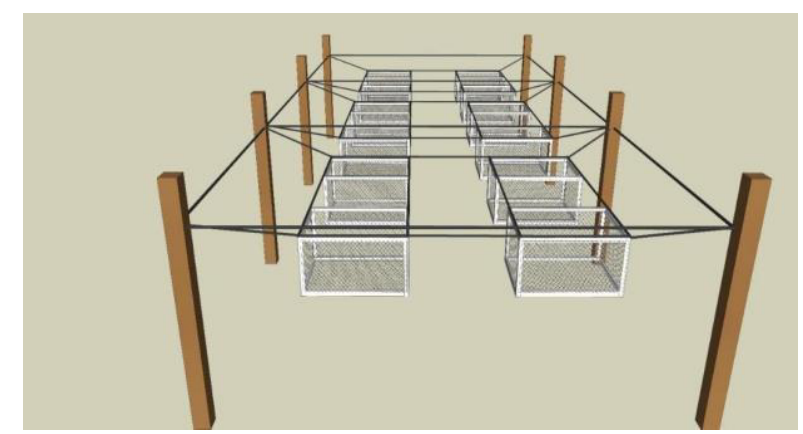

Fig 2. Cultivation Container Illustration 


\subsection{Data Analysis}

\subsubsection{Parameters were observed in the study}

The parameter observed in the study about prevalence of the ectoparasites in green mussels (Perna viridis L.) in Alue Naga, Banda Aceh is the prevalence of ectoparasites. The prevalence of parasites was calculated by using the formula as follows:

\begin{tabular}{cl} 
& \multicolumn{2}{c}{$\begin{array}{l}\text { Samples of infected } \\
\text { prevalenc } \\
\text { e (\%) }\end{array}$} & $\begin{array}{l}\sum \text { examined shellfish } \\
\text { samples }\end{array}$ \\
& sam $\%$
\end{tabular}

$\Sigma$ parasites found

intensity (ind/seed) $\quad \Sigma$ infected shellfish

Prevalence and Intensity category table

Table 1. Prevalence Category

\begin{tabular}{|c|c|l|l}
\hline No & Prevalence & Category & description \\
\hline 1 & $100-99 \%$ & Alway s & Very severe infection \\
\hline 2 & $98-90 \%$ & Almost always & Severe infection \\
\hline 3 & $89-70 \%$ & Usually & Moderate infection \\
\hline 4 & $69-50 \%$ & Very often & Very frequent infection \\
\hline 5 & $49-30 \%$ & Generally & Common infection \\
\hline 6 & $29-10 \%$ & Often & Frequent infections \\
\hline 7 & $9-1 \%$ & Sometimes & Infection sometimes \\
\hline 8 & $1-0.1 \%$ & Seldom & Rare infection \\
\hline 9 & $<0.1-0.1 \%$ & Very rare & Very rare infection \\
\hline 10 & $<0.01$ & Almost no never & Infections do not ever \\
\hline
\end{tabular}

Table 2. Intensity category table

\begin{tabular}{|c|c|c|}
\hline \multirow{2}{*}{ No. } & Intensity & \multirow{2}{*}{ Category } \\
\cline { 2 - 2 } & (eng/tail) & \\
\hline 1 & $<1$ & Very low \\
\hline 2 & $01-$ Mei & Low \\
\hline 3 & Jun-55 & Currently \\
\hline 4 & $51-100$ & Critical \\
\hline 5 & $>100$ & very bad \\
\hline 6 & $>1000$ & super bad \\
\hline
\end{tabular}

\section{Results and Discussion}

\subsection{Type of parasite that infects green mussels (Perna viridis L.)}

Based on the results of the research on ectoparasites in cultivated green mussels (Perna viridis) in the Alue Naga Reservoir, Banda Aceh, there were four types of ectoparasites were found, there are Perkinsus sp cysts. (Protozoa), Balanus sp. (Crustacea), Monogenea (Platyhelminthes) and Copepoda (Crustacea). The complete parasite on green mussels can be seen in Figure 4.1.

\subsection{Green Mussel Ectoparasites (Perna viridis) Based on Microhabitat}

Based on the results of the research that has been done, the type and number of parasites that are found by microhabitat is presented in Table 4.1.1. as follows:

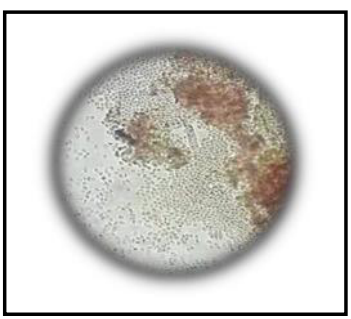

(a)

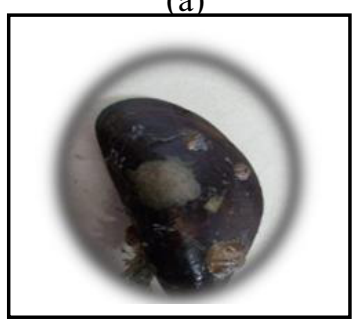

(b)
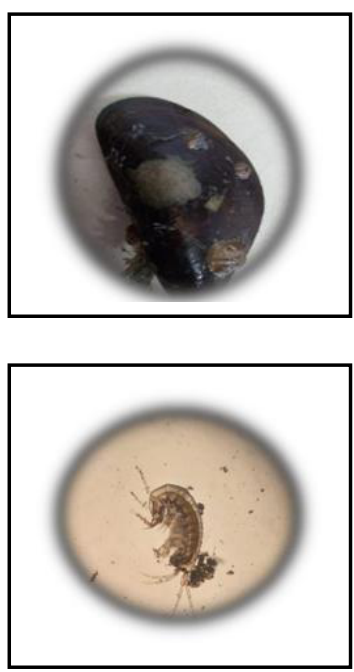

(d)
Fig 3. Parasites infect green mussels ( $P$. viridis) (a) Perkinsus sp. (Protozoa); (b) Balanus sp (Crustacea) (c) Monogenea (Platyhelminthes) (d) Copepods (Crustacea).

Table 3. Types and Numbers of Green Mussel Ectoparasites (P. viridis)

\begin{tabular}{|l|l|l|l|l|c|}
\hline \multirow{2}{*}{ No. } & \multirow{2}{*}{ Name parasite } & \multicolumn{3}{|c|}{ The number parasite } & \multirow{2}{*}{ Total } \\
\cline { 3 - 5 } & & Gill & Coat & Shell & \\
\hline 1 & Perkinsuscyst sp. & - & 1 & - & 1 \\
\hline 2 & Balanus sp. & 86 & - & - & 86 \\
\hline 3 & Monogenea & 21 & - & 5 & 26 \\
\hline 4 & Copepods & 12 & - & 2 & 14 \\
\hline \multicolumn{5}{|c|}{ Total } \\
\hline
\end{tabular}

Table 3 shows that the most common parasite found was Balanus sp. (figure 4.1b) while the least parasite infecting the green mussels was Perkinsus sp. cyst, Balanus sp. that found in the shells of green mussels.

\subsection{Intensity and prevalence Value of ectoparasites in green mussels (Perna viridis)}

Based on table 4, it showed that the highest intensity value is 1.16 and the highest prevalence value is barnacle parasite (Balanus sp.) about 74 , while the lowest intensity value is 1 and the prevalence value is Perkinsus sp cyst about $1 \%$. 
Tabel 4. Intensity and prevalence Value of ectoparasites in green mussels (Perna viridis)

\begin{tabular}{|c|c|c|c|c|c|c|}
\hline \multirow[b]{2}{*}{ No. } & & $\Sigma$ & $\Sigma$ & $\Sigma$ & I & $P$ \\
\hline & Parasite & $\begin{array}{c}\text { Infected } \\
\text { Parasit }\end{array}$ & samples & samples & (Ind) & $(\%)$ \\
\hline 1 & Cyst perkinsus sp. & 1 & 1 & 100 & 1 & $1 \%$ \\
\hline 2 & Balanus sp. & 86 & 74 & 100 & 1.16 & $74 \%$ \\
\hline 3 & Monogenea & 26 & 24 & 100 & 1.08 & $24 \%$ \\
\hline 4 & Copepods & 14 & 10 & 100 & 1.4 & $10 \%$ \\
\hline
\end{tabular}

\subsection{Water quality parameter results}

The results of water quality measurements $(\mathrm{pH}$, temperature, dissolved oxygen, salinity, depth, brightness and current) were carried out at the time of the research and these are fully presented in table 5.

Table 5. Water Quality Parameter Results

\begin{tabular}{|c|l|c|c}
\hline No & $\begin{array}{c}\text { Parameter Quality } \\
\text { Water }\end{array}$ & Unit & $\begin{array}{c}\text { Measurement } \\
\text { Results }\end{array}$ \\
\hline 1 & $\mathrm{Ph}$ & & 8.7 \\
\hline 2 & Temperature & ${ }^{0} \mathrm{C}$ & 29 \\
\hline 3 & Dissolved Oxygen & $\mathrm{Ppm}$ & 4.8 \\
\hline 4 & Salinity & $\mathrm{Ppt}$ & 31 \\
\hline 5 & Depth & Meter & 1.53 \\
\hline 6 & Brightness & $\mathrm{Cm}$ & 70 \\
\hline 7 & Current & $\mathrm{m} / \mathrm{s}$ & 17 \\
\hline
\end{tabular}

\section{Discussion}

\subsection{The Type of Parasite Infects Green Mussels (P. viridis L.)}

Perkinsus sp. cyst parasite. (Figure 4.1a) is a parasite of the phylum Protozoa. The results were obtained during the study's cyst perkinsus sp. That attacks the mantle which shows clinical symptoms, namely the coat shrinks and pale. It refers to the research conducted by [9] who found the same parasites in the green mussel. However, Elston found it in Manila clams ( $V$. philippinarum) and stated that Perkinsus sp. including protozoa that are usually found on the gills and mantel. This parasite is often found or attacks oysters and shellfish.

The number of the cysts perkinsus sp. which is found in the coat scallops green is only one. The number of parasitic cysts perkinsus sp. which is found in the coat is influenced by environmental factors such as temperature and salinity. This statement is also supported by [10] which states that environmental factors affect the development of the parasite Perkinsus sp. cyst. Due to the high temperature and salinity, this infection will increase in the dry season in the estuary area. Chemical factors such as salinity and temperature exceeding about $35.9 \mathrm{ppt}$ and $32^{\circ} \mathrm{C}$ affect the life of mussels. In this case, the salinity will be affected in the setting of internal ions, which directly require energy to transport active ions in order to maintain the internal environment. This is a very effect on physiological processes [11]. The onset of disease in shellfish has a close relationship with environmental conditions so that when the water changes just a bit from the environment then it can lead to shellfish stress because the stress mussels will be easier attacked by the disease.

Balanus $s p$. parasites engaging parasitic organisms has a body that is made from a substance limestone and has a body size of about $1-1.5 \mathrm{~cm}$. According to Jensen [12] said that the Balanus sp. has a body size less than 1 $\mathrm{cm}$ and a maximum of $2 \mathrm{~cm}$. According to [13], the body of Balanus sp. has a calcareous structure. Balanus sp. were found attached on the mussel of the examined green mussel samples. This is supported and in line with [13] statement. They said the body of Balanus $s p$. is attached to a host (shell or carapace). In previous research, Balanus $s p$. has been reported to infect blood clams [14]. Barnacles (Balanus sp.) live in the tidal zone, ranging from tidal highs up to the average tide receded. The economic impact of barnacles tends to lead to negative to all types of the substrate on which it is attached.

During the identification, the Balanus $s p$. is found a lot in the shell of green mussels because barnacles like a rough substrate and are easy to stick to, even Balanus $s p$. not only attached to the shell but also to the hinge of the shell, so that it is difficult for the shell to open and close its shell valve. How the barnacles (Balanus sp.) works is by drilling into the inside of the clamshell so that it can cause death to the clam. These sticking organisms' barnacles (Balanus sp.) attacked the shells indirectly due to its damaging and food competition so that the mussels are slowly impaired growth or broken shells and at end die.

Monogenea parasite (figure 4.1c.) is one of the parasites that often infect fish and invertebrates. It is usually found in external organs by plugging haptors. This parasite easily infects aquatic biota because of its direct life cycle, high reproduction, and high pathogenicity, so it often causes death in fish and other biotas. Monogenean parasites are generally ectoparasites and rarely endoparasites. Monogenea is one of the most common parasites that attack the part of the outside body (ectoparasites), seldom attack a part in the body (endoparasites), and usually affects the skin and gills [15]. Monogenea is a flatworm with a length of 0.15 to $20 \mathrm{~mm}$ and the body is fusiform, haptor (organs part like hooks) in its posterior and the cycle of central hooks pair and a number of hooks marginal.

Parasitic copepods (figure 4.1d.) is a group of shrimp organism that often invades the body of fish and invertebrates as ectoparasites in outer part. In this research, copepods are found in organ gill that is conducted microscopic. This parasite lives in fresh water and seawater and it is quite difficult to control. Most copepod parasites eat by clawing the surface of the host's body using the mandible [16]. They eat mucus, blood tissue of their host, and their attachment and its feeding activity can lead to the primary disease [17]. Several species are major pests in commercial Bilvavian aquaculture such as Ostrincola koe (Myicolidae) lives in the mussel's mantle and causes disease in mussels in China (Boxshall, 2005). 


\subsection{Intensity and Prevalence Value of Ectoparasites in Green Mussels (Perna viridis)}

The intensity value is a value that states or categorizes the level of infected biota from low category $(<1)$ to superinfection $(>1000)$. Meanwhile, the prevalence is the value that states into a category that is often infected ranging from category always (99-100\%) and the category is almost not never $(<0.01)$. Based on the results of the study, it was known that from 100 samples of green mussels examined, there were 88 individual green mussels that were attacked by the disease so that the green mussels were free from parasites and were not deformed were counted 12 individuals of green mussels.

Based on table 4.1.2, it is known that the highest intensity value is 1.16 and the highest prevalence value is barnacle parasite type about $74 \%$, (Balanus $s p$.), while the lowest intensity value is 1 and the prevalence value of Perkinsus sp cyst is 1\%. Prevalence value of $1 \%$ with the description "occasional infection" which means the spread of the parasite Perkinsus sp cyst is not frequent on green mussels which are still in the "sometimes" category. Prevalence value about 74\% with a description "moderate infection" with the category "usually" are parasites Balanus sp. (barnacles) that attacked green mussels in the Alue Naga Reservoir, Banda Aceh. Prevalence Value about $10 \%$ and 24\% showed that there were often occur infections in mussels green with category "frequent". The intensity value of 1 - of 1.16 is still in the low category, which means the infection of parasites on each individual is still low or not including infection is very severe.

\subsection{Water quality parameter results}

Table 5 showed that the temperature was around $29^{\circ} \mathrm{C}$ and several previous studies stated that the optimal temperature to support the growth of green mussels was $27^{\circ} \mathrm{C}-30^{\circ} \mathrm{C}[19]$. Salinity at the location of green mussel cultivation in Alue Naga waters, Banda Aceh is around 31 ppt. According to [20], green mussels can still live in the salinity range between 15-45 ppt. [21] also explained that the mussel green indicates that good growth in the estuary is with a salinity range of $18-33$ ppt. The concentration of oxygen dissolved range at the location of the cultivation of green mussels is from 4.8 to 6.5 ppm. According to [22], the concentration of Dissolved oxygen range that can still be tolerated by green mussels is $2-12 \mathrm{mg} / \mathrm{L}$. The level of acidity or $\mathrm{pH}$ range in the waters of green mussel cultivation is from 8.7. According to [22], the $\mathrm{pH}$ range which still can be tolerated by green mussels is from 7-9. The speed ranges of water currents during the green shell cultivation site are from $17 \mathrm{~m} / \mathrm{s}$. The suitable current speed ranges for green shellfish cultivation activities are from 0.1 to 0.6 $\mathrm{m} / \mathrm{s}[15 ; 21]$.

\section{Conclusion}

Based on the results of the research on ectoparasites in cultivated green mussels (Perna Viridis) in the Alue Naga Reservoir, Banda Aceh, there were 4 types of ectoparasites, there are Perkinsus sp cysts. (Protozoa), Balanus sp. (Crustacea), Monogenea (Platyhelminthes), and Copepoda (Crustacea). The barnacle parasite (Balanus sp.) has the highest intensity value 1.16 and the highest prevalence value $74 \%$, while the Perkinsus sp cyst has the lowest intensity value 1 and the prevalence value $1 \%$.

\section{References}

1. Hendrik AWC. Oceana. 33, 33-40. (2008).

2. Prasetyo, A. D. Determination of Metal Content ( $\mathrm{Hg}, \mathrm{Pb}, \mathrm{Cd})$ with the Addition of Preservatives and Different Soaking Times in Green Mussels (Perna viridis L.) in Muara Kamal Waters, Jakarta Bay. Thesis. Syarif Hidayatullah State Islamic University. (2009).

3. Kordi, K. Management of Fish Pests and Diseases. Rineka copyright and Bina Adiaksara. Jakarta. (2004).

4. Bhakti, S. Prevalence and Identification of Ectoparasites in Koi Fish (Cyprinus carpio) in Several Locations of Ornamental Fish Cultivation in East Java. Thesis. Faculty of Veterinary Medicine. Airlangga University. Surabaya. (2011).

5. Ichsan, Mahmudi M, Nuddin H. The carrying capacity of the Blue Economy-Based Aquatic Environment on the Production of Vanname Shrimp Aquaculture in the Probolinggo Coastal Area. Postgraduate Program, Faculty of Fisheries and Marine Sciences, Universitas Brawijaya, Proceedings of the National Seminar of the University of Muhammadiyah Gresik pages 7992. (2013).

6. Decree of the State Minister of the Environment, Number 51 of 2004 Regarding Standard Quality of Seawater, State Minister of the Environment, Republic of Indonesia

7. Nguyen, V.T. The influences of shrimp farming and fishing practices on natural fish conservation in Can Gio, Ho Chi Minh City, Vietnam. Ph.D. Thesis, University of Newcastle. (2008)

8. Ichsan. Receptacle Engineering and Aquaculture Technology, UB Press, Malang. (2012)

9. Elston, R.A, Dungan, C.F, Meyers, T.R, and Reece, K.S. J. of Shellfish Research. 22, 661665. (2003).

10. Soniat, T.M. Levels of the parasite Perkinsus marinus in populations of oysters from the Louisiana Public Seed Ground: Summer 2012, Louisiana: Louisiana Department of Wildlife and Fisheries. (2012)

11. Susiana, A. Niartiningsih and M. A Amran. The Relationship Between Water Quality Suitability and Kima (Tridacnidae) Abundance in the 
Spermonde Islands. Faculty of Marine Sciences and Fisheries Hasanuddin University Makassar. (2016).

12. Jensen, KR 2010. NOBANIS - Invasive Alien Species Fact Sheet. Denmark.

13. Alsaqabi, S., Albelali, A. S., Eshky, A. A. J. of Scientific Research, 30: 141-149. (2012)

14. Rahmawan, F. 2013. Prevalence of Ectoparasites in Blood Shellfish (Anadara granosa) Captured by Fishermen in the Sidoarjo Region, East Java. Thesis of the Faculty of Marine Affairs and Fisheries, Airlangga University.

15. Kabata Z. 1985. Parasites and Diseases of Fish Cultured in the Tropics. Taylor \& Francis, London \& Philadelphia.

16. Boxshall GA. 2005. Crustacean parasites (Chapter 4). In: K Rohde (Ed). Marine Parasitology, 123-169. CABI Publishing, Wallingford.

17. Johnson SC, JW Treasurer, S Bravo, K Nagasawa and Z Kabata. Zoological Studies. 43, 229-243 (2004)

18. Boxshall G.A. Marine Parasitology, 123-169. CABI Publishing, (2005).

19. Aypa, SM 1990. Mussel Culture : Regional sea Farming Development and Demonstration project (p. 210). Bangkok. National Inland Fisheries Institute. Kasetsart University.

20. McGuire, M. \& Stevely, J. (2009). Invasive species of Florida's coastal waters : the asian green mussel (Perna viridis). The Florida Sea Grant College Program with support from the National Oceanic and Atmospheric Administration. US Department of Commerce.

21. [FIGIS] Fisheries Global Information System. Species Fact Sheet: Perna viridis (Linnaeus, 1758) Mytilidae . Rome : FAO. (2005)

22. Sreedevi, P.R., Uthayakumar, V., Jayakumar, R., Joseph, Kumar, D. S. \& Ramasubramanian, V. World Journal of Fish and Marine Science, 6, 487 - 493 (2014)

23. Alfaro, A.C. Aquaculture. 246, 285 - 294, (2005) 